\title{
Recovery of the Microstructural Changes of Different Duplex Stainless-Steel Alloys
}

\begin{tabular}{|r|l|}
\hline Journal: & Multidiscipline Modeling in Materials and Structures \\
\hline Manuscript ID & MMMS-06-2020-0148.R2 \\
\hline Manuscript Type: & Research Paper \\
\hline Keywords: & $\begin{array}{l}\text { Super duplex stainless steel, microstructure, ferrite content, recovery, } \\
\text { intermetallic phase }\end{array}$ \\
\hline \multicolumn{2}{|l}{} \\
\hline
\end{tabular}

\section{SCHOLARONE \\ Manuscripts}




\title{
Recovery of the Microstructural Changes of Different Duplex Stainless-Steel Alloys
}

\begin{abstract}
Purpose - To find out the optimum heat treatments to recover the microstructural changes of stainless-steel alloys. Design/methodology/approach - Four alloys were used in this study, two duplex stainless-steel alloys type 2304 and 2205, super duplex stainless steel type 2507 and austenitic stainless-steel alloy type 316L. The alloys were heated to different temperatures, $750,850,950$ and $1050{ }^{\circ} \mathrm{C}$, for three different times $10 \mathrm{~min}, 1 \mathrm{hr}$ and $4 \mathrm{hrs}$. Findings - The microstructural investigations showed that 2205 and 2507 were behaved similarly in recovering their microstructures, especially in terms of ferrite:austenite ratio within specific heat treatments and changing the hardness values. The results showed that the microstructure of both alloys was started to change above $750{ }^{\circ} \mathrm{C}$, the largest changes were shown at $850{ }^{\circ} \mathrm{C}$ and $950{ }^{\circ} \mathrm{C}$, as the lowest ferrite content was recorded at $850{ }^{\circ} \mathrm{C}$ for both alloys. However, the microstructures of both alloys were started to recover at $1050{ }^{\circ} \mathrm{C}$. The reduction in the hardness values was attributed to the formation of residual stress free ferrite grains. On the other hand, the microstructure of the alloy type 2304 was stable and did not show large changes due to the applied heat treatments, similarly for austenitic alloy except showing chromium carbide precipitation.

Research limitations/implications - The microstructural changes which associate with the heat treatments have been recovered for two alloys, further works can be done on welded samples for similar alloys.

Originality/value - Finding the exact heat treatments, temperature and time, to recover the microstructural changes of duplex stainless-steel alloys.
\end{abstract}

Keywords:

Super duplex stainless steel, microstructure, ferrite content, recovery, intermetallic phase

\section{Introduction}

The reason behind the globally rapid growth of the increase in demand and consumption of duplex stainless-steel DSS in petrochemicals, marine and power stations and other engineering applications, is mainly due to the chemical composition, consequently the formation of a microstructure of two phases, ferrite and austenite, which provides high strength and corrosion resistance in harsh environments [1]. However, heating stainless-steel alloys - during welding and heat treatments - remains challenging while they pass through a range of temperatures, specifically from 500 to $1100{ }^{\circ} \mathrm{C}$ [2][3]. The changes, besides the formation of embrittlement phases such as sigma and chi phases, and carbide and nitride precipitations, also include an imbalance phase ratio of austenite/ferrite which leads to the change of the mechanical properties and corrosion resistance [4] [5] [6].

Many researchers have worked on investigating the microstructural changes that associate with welding and heat treatments. Arabi et al [7] studied the effect of spot welding on DSS type 2304 through controlling downsloping current and in situ post-weld short annealing of the weld. Both ways enabled enhancing the austenite volume fraction in the fusion zone. Tan et al [8] studied pitting corrosion resistance of 2304 after autogenous plasma-arc welding and subsequent short-time post-weld heat treatment at different temperatures. The results showed that the most favorable annealing temperature for the analyzed welded joints was found to be $1080^{\circ} \mathrm{C}$, at which the joint restored the pitting corrosion resistance lost during welding entirely. Alinejad et al [9] studied thermomechanical characteristics of type 2304 at a temperature range from 850 to $1150{ }^{\circ} \mathrm{C}$. Microstructural observations showed that dynamic recovery in ferrite is the controlling mechanism at all deformation conditions [10].

Khoshnaw [11] studied the effect of welding heat input, using tungsten inert gas TIG, on stress corrosion cracking of austenitic stainless-steel type 304L and DDS type 2205. The results showed that increasing the heat input causes brittleness for both alloys. However, the duplex alloy showed higher resistance to SCC than the austenitic alloy due to higher Cr content and the dual phases. In another study, Khoshnaw et al [12] worked on the same alloys, focused on the metallurgical aspects, such as intermetallic compound precipitation, that associate with heating from 500 to $1100{ }^{\circ} \mathrm{C}$ using thermal cycle simulator. The results showed that less than one minute is enough to allow the carbides precipitate in both alloys, as no intermetallic phases were appeared due to the short time.

Kashiwar et al [13] investigated the effect of the solution annealing of alloy type 2205 at $1050{ }^{\circ} \mathrm{C}$ and $1100{ }^{\circ} \mathrm{C}$, also isothermally aged at $700^{\circ} \mathrm{C}$ for $15 \mathrm{~min}$ to $6 \mathrm{hrs}$. The results showed that a significant amount of carbides was observed in the ferrite grains after $1 \mathrm{~h}$ of aging at $700{ }^{\circ} \mathrm{C}$. Cronemberger et al 
[14] found that the intermetallic compound formation in DDS type 2205 increases the brittleness and decreases its corrosion resistance. Badji et al [15] studied the effect of the subsequent annealing treatment on the phase transformations and mechanical behavior of welded DSS 2205. The results showed that the temperatures from 800 to $1000^{\circ} \mathrm{C}$ resulted in precipitation of sigma phase and chromium carbides. Optimal mechanical properties and an acceptable ferrite:austenite ratio throughout the weld regions correspond to annealing at $1050{ }^{\circ} \mathrm{C}$. Zhang et al [16] studied the same alloy in terms of the effect of nitrogen content on the pitting corrosion resistance. They showed that nitrogen facilitates primary austenite formation in the weld metal and suppressed $\mathrm{Cr}_{2} \mathrm{~N}$ precipitation. Deng et al [17] also studied the microstructure and properties of the same alloy following isothermally aging from 450 to $1000{ }^{\circ} \mathrm{C}$ for $10 \mathrm{~min}$. The results showed that temperatures from 600 and $950{ }^{\circ} \mathrm{C}$ resulted in precipitation secondary phases, which had a significant reduction in pitting corrosion resistance.

Danut et al [18] investigated the microstructural changes induced by solution treatment of super duplex stainless steel - SDSS alloy type F53, 45\% ferrite and 55\%, to emphasize the correlation between the component phases and the heat treatments. Samples were heated at $1100{ }^{\circ} \mathrm{C}$, with variable holding times: $10 \mathrm{~min}, 60 \mathrm{~min}$ and $180 \mathrm{~min}$. Ciuffini et al [19] also attempted to show this correlation, the changes of ferrite:austenite ratio, with the heating temperature of two SDSS alloys: F53-S32750 and F55-S32760. They found that heating at $1080^{\circ} \mathrm{C}$ gives the best ratio. Pettersson et al [20] evaluated the changes in mechanical properties of SDSS type 2507 during aging at $300{ }^{\circ} \mathrm{C}$ up to $12,000 \mathrm{~h}$. Both transmission electron microscopy TEM and atom probe tomography were used to follow $\mathrm{Cr}$ concentration fluctuations, which was proportional to the hardness of the ferrite phase, and the decrease of impact toughness [21]. Argandoña et al [5] studied the alloy UNS S32760, which showed that the resulting hardness values were increased as a function of a longer heat treatment duration which was associated with the formation of a higher percentage of the sigma phase. However, nanoindentation hardness measurements of this phase showed lower values than expected, being a combination of two main factors, namely the complexity of the phase structure as well as the surface roughness. Calliari et al [22] studied the effect of heating from 750 to $1000{ }^{\circ} \mathrm{C}$ on four types of alloys; 2205, 2507, 2304, and 2101 to study the formation of secondary phases of isothermally aged samples. The results indicated the precipitation of intermetallic phases for 2205 and 2507 grades. On the contrary, the secondary phases are rarely observed after both isothermal aging, up to $750 \mathrm{hrs}$ for 2304 and 2101.

The above review has shown that many researchers, in the last two decades, focused on finding new metallurgical changes which associate with heating stainless-steel alloys and investigating the effects on mechanical and corrosion behavior [23] [2]. However, much lesser researches can be found who has focused on studying the methods to recover the changes which are associate with welding and heat treatments. Based on that, to fill part of this gap, this research aims to find the optimum heat treatments which can recover the microstructural changes of a few DSS alloys back to the original manufacture setup microstructure.

\section{Materials and Experimental Works}

In the previous study[12] a thermal cycle investigator was used to investigate the heating treatments of DSS type 2205 and austenitic type 304L within a sensitization range, from 500 to $1100{ }^{\circ} \mathrm{C}$. In this study, almost the same temperatures, but for longer times, were applied on four types of stainless-steel alloys, which are: two DSS type 2205 and 2304, super duplex type 2507 and austenitic type 316L. Table 1 shows the chemical composition of the alloys. Plates, with thicknesses from 8 to $12 \mathrm{~mm}$, were cut to samples, $50 \times 10 \mathrm{~mm}$. Different heat treatments - heating to different temperatures and keeping the sample at specific times - were applied, starting from 750 to $1050{ }^{\circ} \mathrm{C}$ - the interval increase was $100^{\circ} \mathrm{C}$ - for different times: 10 minutes, 1 hour and 4 hours.

To proceed with microstructural investigations, samples were prepared following grinding, polishing and etching. Two etching solutions were used, for DSS alloys the electrochemical etching device type Struers LecroPol-5 was used in $45 \mathrm{gm} \mathrm{KOH}$ in $60 \mathrm{ml}$ distilled water, applying 2.5 Volt, for $4-5$ seconds, at room temperature. For austenitic stainless steel, immersion in solution $10 \mathrm{ml} \mathrm{HCL}, 5 \mathrm{ml} \mathrm{HNO}_{3}$ and distilled water, for 4 minutes was applied. Microstructural images were prepared for the as-received and heat-treated alloys at different temperatures and times under consideration in this study. Scanning electron microscope type JEOL-SEM 6400 is used to observe the microstructural changes. 
Table 1 Chemical composition in \%wt of the used alloys

\begin{tabular}{|l|l|l|l|l|l|l|l|l|}
\hline Alloys & $\mathrm{Cr}$ & $\mathrm{Ni}$ & $\mathrm{C}$ & $\mathrm{Mn}$ & $\mathrm{Mo}$ & $\mathrm{Si}$ & $\mathrm{Cu}$ & $\mathrm{N}$ \\
\hline 2304 & 23.15 & 3.40 & 0.03 & 0.60 & 0.3 & 0.26 & 0.26 & 0.09 \\
\hline 2205 & 22.70 & 5.15 & 0.02 & 1.95 & 3.2 & 0.75 & 0.24 & 0.21 \\
\hline 2507 & 24.70 & 7.15 & 0.02 & 1.05 & 3.8 & 0.35 & 0.20 & 0.32 \\
\hline $316 \mathrm{~L}$ & 17.50 & 10.1 & 0.03 & 1.77 & 2.7 & 0.32 & 0.33 & --- \\
\hline
\end{tabular}

A ferrite measurement device, type Ferritgehalt-messer, was used to detect the changes in the ferrite content FC\% of the heat-treated alloys, compared with the as-received samples [24]. The device shows the ferrite number, FN, based upon an arbitrarily defined relationship between the magnetic susceptibility of the samples and the ferrite content. The FN is converted to FC\% - as recommended by the device supplier - based on the following equation:

\section{Results}

$$
\text { Ferrite Content } \%=7.30583 \times e^{\frac{F N}{8.88399}}-7.162
$$

Table 2 shows the FC\% values of the as-received and heat-treated alloys. The Hardness Rockwell C HRC machine, type Emco was used to measure the hardness of the samples after they were ground and polished. Fig. 1 shows the HRC hardness values of all the heat-treated samples, the first bar chart in each figure shows the hardness of the as-received condition of the alloy under consideration.

Table 2 Ferrite $\%$ of the as-received and heat-treated alloys

\begin{tabular}{|l|l|l|l|l|}
\hline \multirow{2}{*}{ Alloys } & \multirow{2}{*}{$\begin{array}{l}\text { Temp. } \\
\text { 'C }\end{array}$} & \multicolumn{3}{|c|}{ Ferrite \% } \\
\cline { 3 - 5 } & & \multicolumn{3}{|c|}{ Time } \\
\cline { 2 - 5 } & $10 \mathrm{~min}$ & $1 \mathrm{hr}$ & $4 \mathrm{hrs}$ \\
\hline 2304 & 750 & 66.2 & 54.8 & 54.8 \\
\cline { 2 - 5 } $\begin{array}{l}\text { As received }= \\
66.2 \% \text { Ferrite }\end{array}$ & 850 & 54.8 & 54.8 & 54.8 \\
\cline { 2 - 5 } & 950 & 62.2 & 62.2 & 58.4 \\
\cline { 2 - 5 } & 1050 & 62.2 & 62.2 & 66.2 \\
\hline $\begin{array}{l}2205 \\
\text { As received }=\end{array}=$ & 750 & 42.3 & 24.2 & 10.2 \\
\cline { 2 - 5 } $54.8 \%$ Ferrite & 850 & 15.3 & 14.3 & 9.7 \\
\cline { 2 - 5 } & 950 & 28.1 & 28.1 & 15.1 \\
\cline { 2 - 5 } & 1050 & $\mathbf{5 4 . 8}$ & $\mathbf{4 3 . 4}$ & $\mathbf{5 8 . 4}$ \\
\hline $\begin{array}{l}2507 \\
\text { As received }= \\
66.2 \% \text { Ferrite }\end{array}$ & 750 & 45.2 & 37.0 & 10.2 \\
\cline { 2 - 5 } & 850 & 18.0 & 16.0 & 14.0 \\
\cline { 2 - 5 } & 950 & 17.2 & 15.6 & 15.6 \\
\cline { 2 - 5 } & 1050 & $\mathbf{4 8 . 2}$ & $\mathbf{5 4 . 8}$ & $\mathbf{6 4 . 8}$ \\
\hline $316 \mathrm{~L}$ & 750 & 0.6 & 0.6 & 0.6 \\
\cline { 2 - 5 } As received $=$ & 850 & 0.4 & 0.3 & 0.3 \\
\cline { 2 - 5 } $0.5 \%$ Ferrite & 950 & 0.4 & 0.2 & 0.2 \\
\cline { 2 - 5 } & 1050 & 0.2 & 0.2 & 0.2 \\
\hline
\end{tabular}



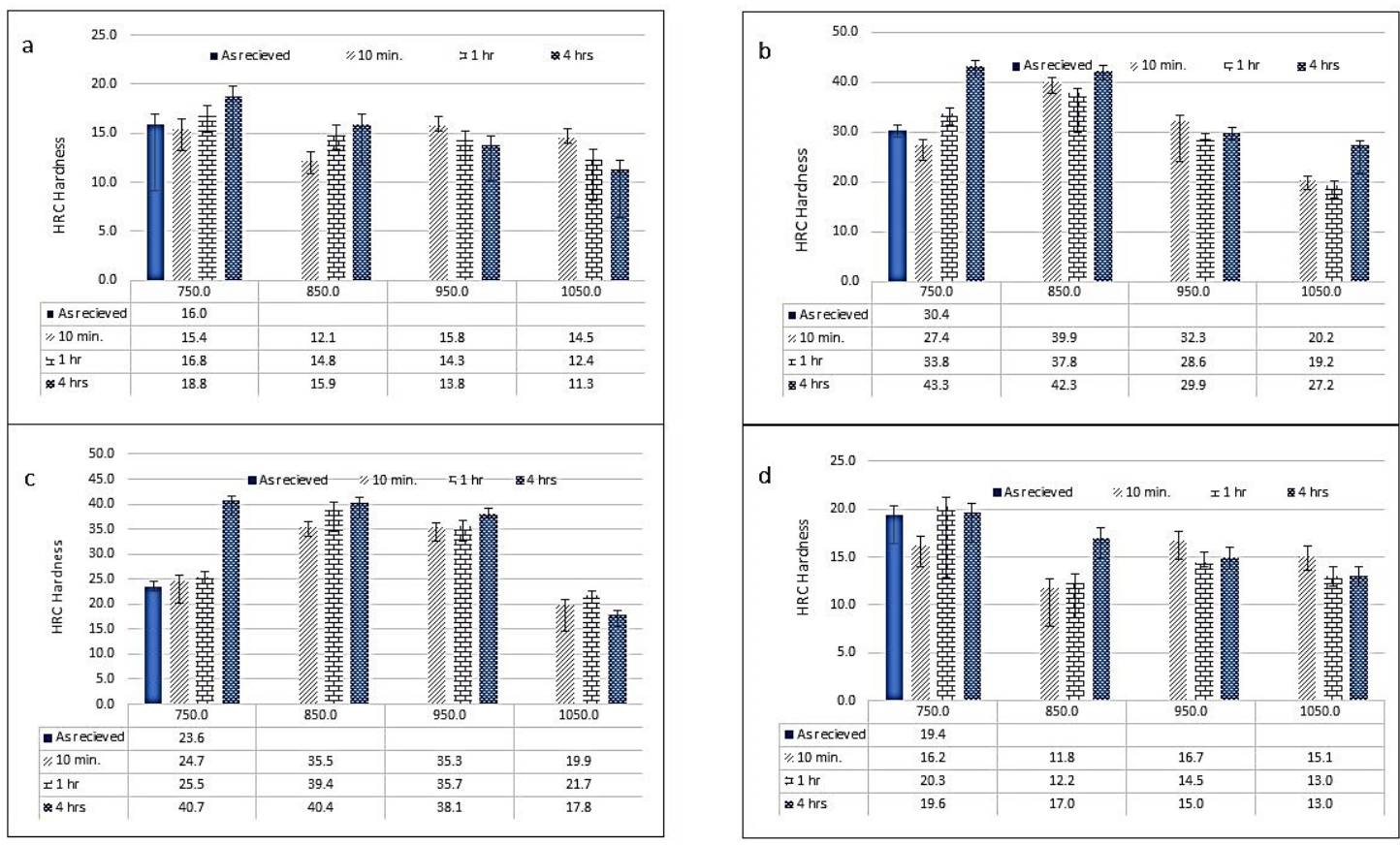

Fig. 1 Rockwell-C Hardness values of as-received and heat-treated alloys at different temperatures and times, a: 2304 alloy, b: 2205 alloy, c: 2507 alloy, d: 316L

\section{DSS Alloy Type 2304}

Fig. 2a shows the as-received microstructure, which consisted of both ferrite and austenite phases. Fig. 2b-d show microstructural images of samples that cover heat treatments from the lowest to highest temperatures for different times; which are $750{ }^{\circ} \mathrm{C}$ for $10 \mathrm{~min}, 950{ }^{\circ} \mathrm{C}$ for $1 \mathrm{hr}$ and $1050{ }^{\circ} \mathrm{C}$ for $4 \mathrm{hrs}$ respectively. The images show that there are no noticeable changes were observed in this alloy due to applying the heat treatments. Similarly, Table 2 shows that there are no large fluctuations associate with FC\% due to the applied heat treatments. The as-received alloy and heat-treated alloy at $1050{ }^{\circ} \mathrm{C}$ for 4 hrs had the highest FC\% equal to $66.2 \%$, while the minimum amount, equal to $54.8 \%$, was observed at $850{ }^{\circ} \mathrm{C}$ for all times. In terms of the hardness test, Fig. 1a shows no large changes in hardness values by applying different heat treatments compared with the as-received alloy. The highest and lowest hardness values were 21 and $14 \mathrm{HRC}$, belong to the heat-treated alloys at $750{ }^{\circ} \mathrm{C}$ and $1050{ }^{\circ} \mathrm{C}$ respectively (both for 4 hours). The hardness values for samples heated at $850{ }^{\circ} \mathrm{C}$ and $950{ }^{\circ} \mathrm{C}$ for different times were either equal or slightly lower than the as-received alloy. 

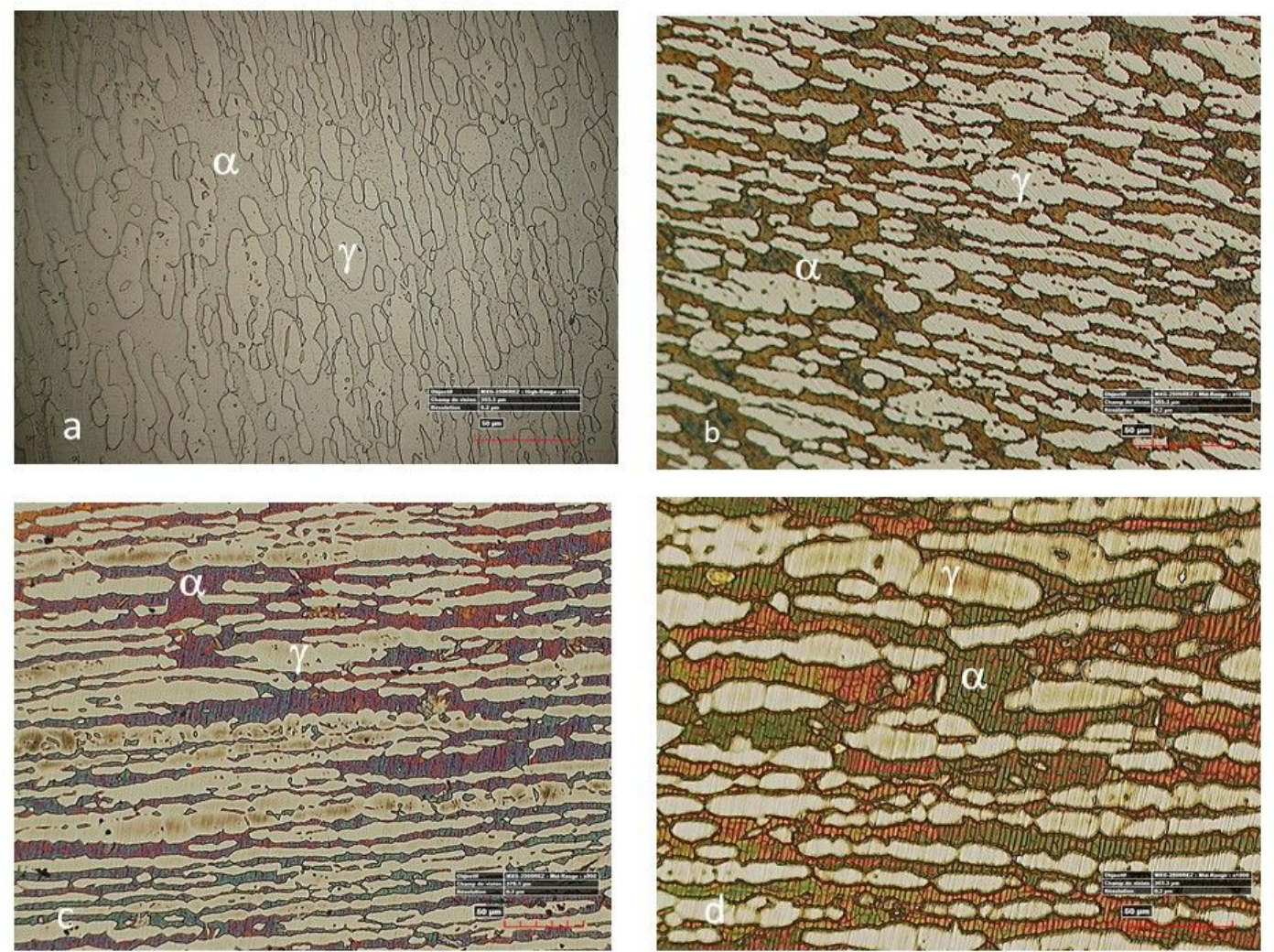

Fig. 2 Microstructure of DSS 2304, a: as received, b: $750{ }^{\circ} \mathrm{C}$ for 10 min., c: $950{ }^{\circ} \mathrm{C}$ for $1 \mathrm{hr}$, d: 1050 ${ }^{\circ} \mathrm{C}$ for $4 \mathrm{hrs}$.

\section{DSS Alloy Type 2205}

Table 2 shows that $\mathrm{FC} \%$ of the as-received 2205 alloy was $54.8 \%$. This number was decreased by increasing the temperature and time, from 750 to $950^{\circ} \mathrm{C}$, however the lowest ferrite content shown in $850^{\circ} \mathrm{C}$ for all times. At $1050^{\circ} \mathrm{C}$ - for $10 \mathrm{~min}$, the ferrite content was started to increase and reached the highest amount, 58.4\% in $4 \mathrm{hrs}$. In return, the investigations for the microstructural images approved the occurrence of such changes, Fig. 3 shows microstructures of samples that heat-treated at different temperatures and times. Fig. 3a shows the as-received DSS alloy type 2205, which almost shows a $50: 50$ of ferrite:austenite ratio. Fig. 3b-d show microstructure of heat-treated samples at $850{ }^{\circ} \mathrm{C}$ for 10 $\min , 950{ }^{\circ} \mathrm{C}$ for $1 \mathrm{hr}$ and $1050^{\circ} \mathrm{C}$ for $4 \mathrm{hrs}$ respectively. Large similarities can be seen between the asreceived and heated at $1050^{\circ} \mathrm{C}$ samples, while the other samples heated to $850^{\circ} \mathrm{C}$ and $950{ }^{\circ} \mathrm{C}$ (especially for $4 \mathrm{hrs}$ ) showed the lowest FC\%, and their microstructures, see Fig. 3b and c, which show residual stress free ferrite grains, shapes and sizes due to the occurrence of the recrystallization phenomenon [9] [15] [19] [25] [13]. On the other hand, Fig. 1b shows that the hardness was increased to the highest values, around $43 \mathrm{HRC}$, during heating at $750^{\circ} \mathrm{C}$ and $850^{\circ} \mathrm{C}$ (both for $4 \mathrm{hrs}$ ) - compared to the hardness of the as-received condition equals to $30 \mathrm{HRC}$. At $950^{\circ} \mathrm{C}$ for all times, the hardness values were almost similar to the as-received alloy, while at $1050{ }^{\circ} \mathrm{C}$, the hardness values were noticeably reduced to around $20 \mathrm{HRC}$, especially for $10 \mathrm{~min}$ and $1 \mathrm{hr}$ heating. 

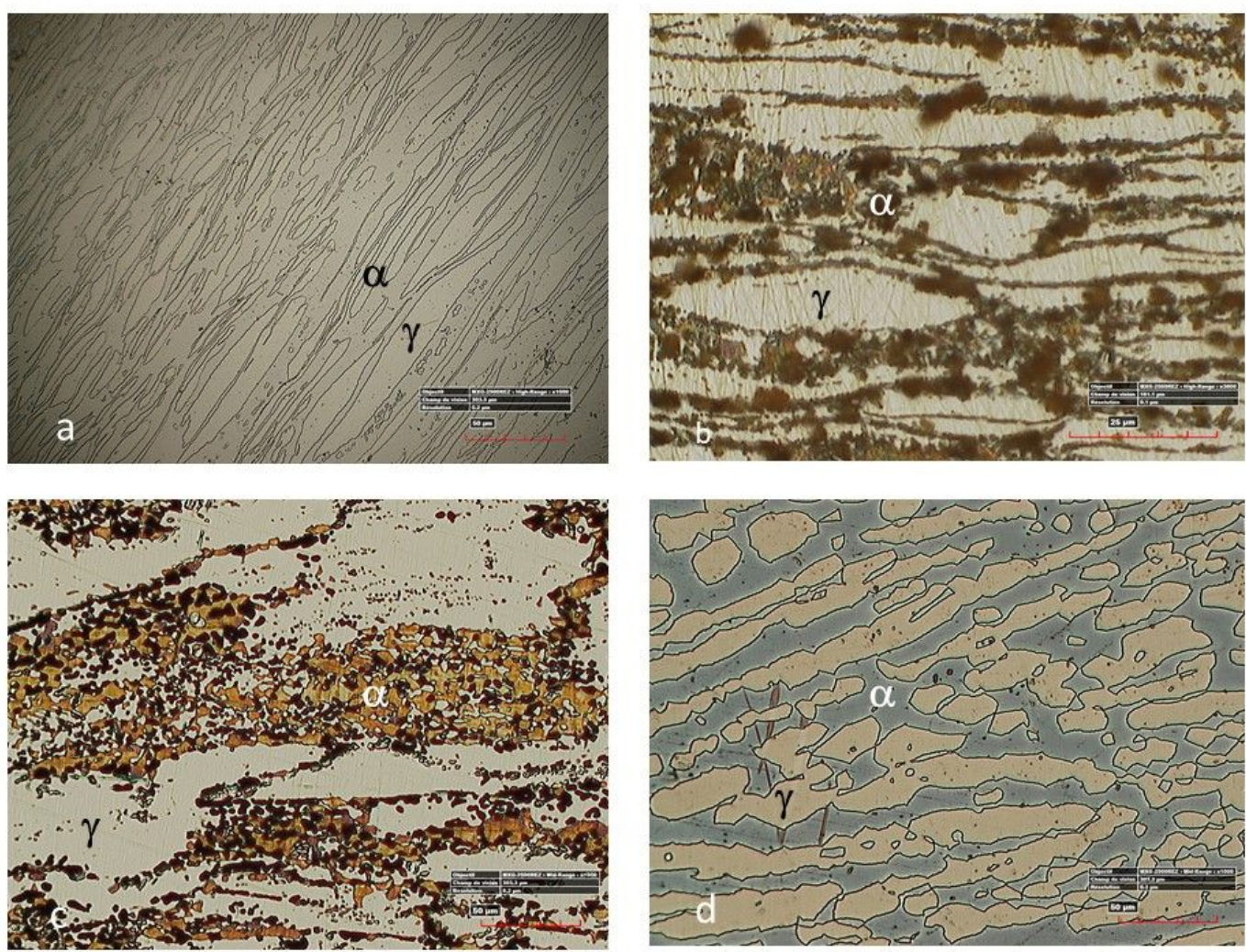

Fig. 3 Microstructure of DDS 2205, a: as received, b: $850{ }^{\circ} \mathrm{C} 10 \mathrm{~min}$., c: $950^{\circ} \mathrm{C}$ for $1 \mathrm{hr}$, d: $1050{ }^{\circ} \mathrm{C}$ for $4 \mathrm{hrs}$. 


\section{SDSS Alloy Type 2507}

Table 2 shows that the ferrite content of the as-received SDSS alloy type 2507 was $66.2 \%$. At $750{ }^{\circ} \mathrm{C}$, $\mathrm{FC} \%$ has started the reduction with increasing the heating time, while at 850 and $950{ }^{\circ} \mathrm{C}$, the values were dramatically reduced, reached $14 \%$. At $1050^{\circ} \mathrm{C}$, the $\mathrm{FC} \%$ was increased with increasing the time, almost recovered to reach the same value of the as-received alloy. The investigations of microstructural images support these changes, Fig. 4a shows the as-received alloy of 2507, which shows a balanced ratio of both ferrite and austenite. Fig. $4 \mathrm{~b}-\mathrm{d}$ show the microstructure of samples which heat-treated at $850{ }^{\circ} \mathrm{C}$ for $10 \mathrm{~min}, 950{ }^{\circ} \mathrm{C}$ for $1 \mathrm{hr}$ and $1050^{\circ} \mathrm{C}$ for $4 \mathrm{hrs}$ respectively. These figures show that there are large similarities between the as-received and $1050^{\circ} \mathrm{C}$ samples, while the other samples, treated at the other temperatures, show different grain shapes and sizes. In terms of the hardness values, Fig. $2 \mathrm{c}$ shows that the as-received 2507 alloy was $24 \mathrm{HRC}$, and the highest hardness values, around $40 \mathrm{HRC}$, were measured for samples heated at 850 and $950{ }^{\circ} \mathrm{C}$ for all times, also at $750{ }^{\circ} \mathrm{C}$ but only for $4 \mathrm{hrs}$. Similar hardness values to the as-received alloy were obtained only at $750{ }^{\circ} \mathrm{C}$, for $10 \mathrm{~min}$ and $1 \mathrm{hr}$. All the samples which heat treated at $1050{ }^{\circ} \mathrm{C}$ had hardness values lower than the as-received alloy, especially for 4 hrs was equal to $18 \mathrm{HRC}$.
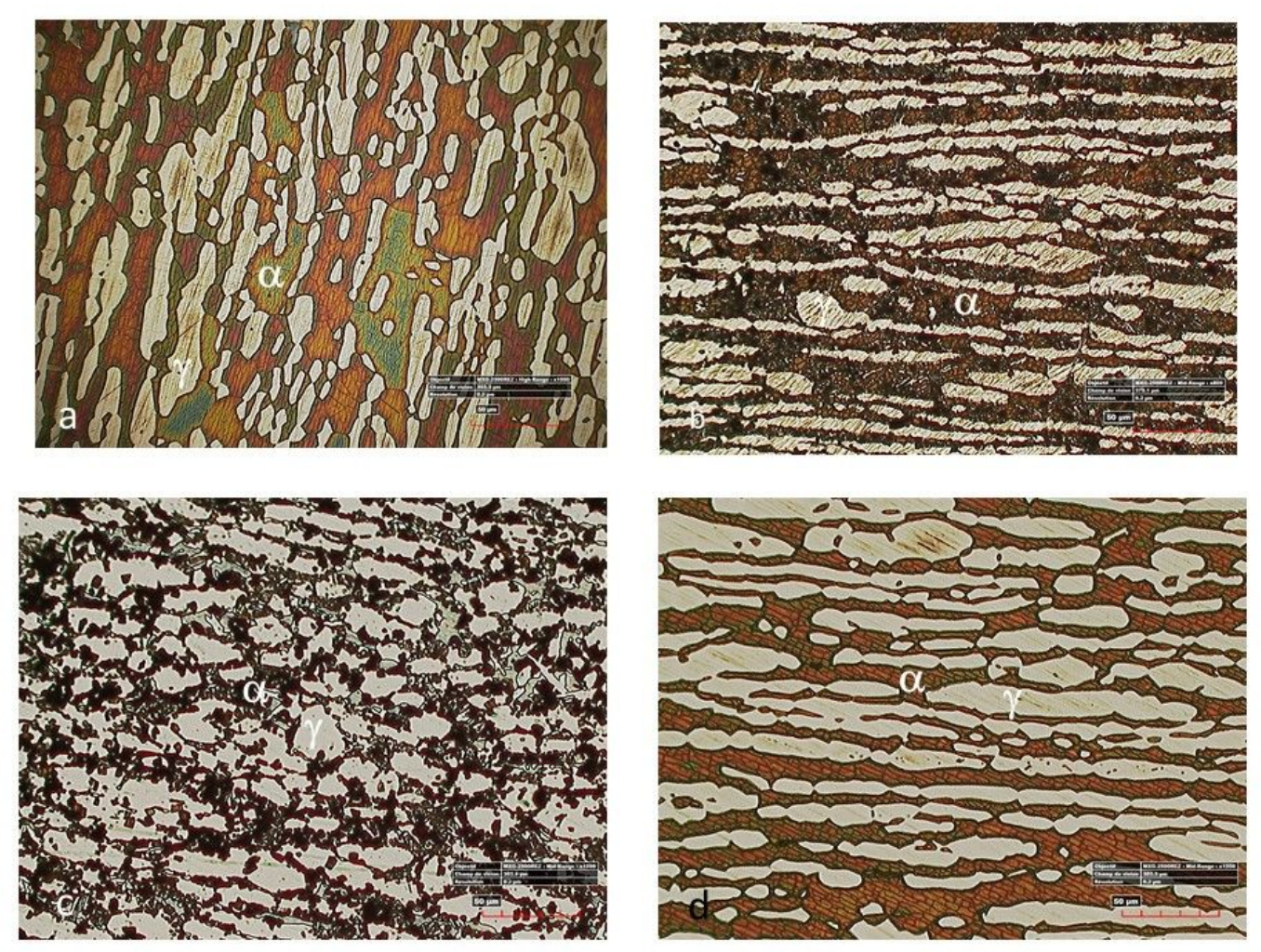

Fig. 4 Microstructure of DDS 2507, a: as received, b: $850^{\circ} \mathrm{C} 10$ min., c: $950^{\circ} \mathrm{C}$ for $1 \mathrm{hr}$, d: $1050{ }^{\circ} \mathrm{C}$ for $4 \mathrm{hrs}$.

Austenitic St. St. Alloy Type 316L

In general, this type of alloy did not show noticeable changes - after applying the heat treatments - on the microstructure and hardness values. Fig. 5a shows austenite as the microstructure of the as-received alloy, which is similar to Fig. $5 \mathrm{~d}$, the heat-treated sample at $1050^{\circ} \mathrm{C}$ for $10 \mathrm{~min}$. However, Figures $5 \mathrm{~b}$ and c, show the microstructure of the heat-treated alloys at $750{ }^{\circ} \mathrm{C}$ and $850{ }^{\circ} \mathrm{C}-$ both for $1 \mathrm{hrs}-$ which show carbide precipitation on the grain boundaries, which attributed to passing the alloy through the sensitization range [12]. In terms of ferrite content, Table 2 shows that, because the microstructure is austenitic, almost no ferrite was observed, as the highest FC\% did not exceed $0.6 \%$. Fig. $2 \mathrm{~d}$ shows that the hardness of the as-received alloy was $19 \mathrm{HRC}$, the hardness values were decreased for samples heated at higher temperatures and longer times, and the lowest hardness value, $12 \mathrm{HRC}$, was observed 
at $850{ }^{\circ} \mathrm{C}$ for $10 \mathrm{~min}$ and $1 \mathrm{hr}$. 

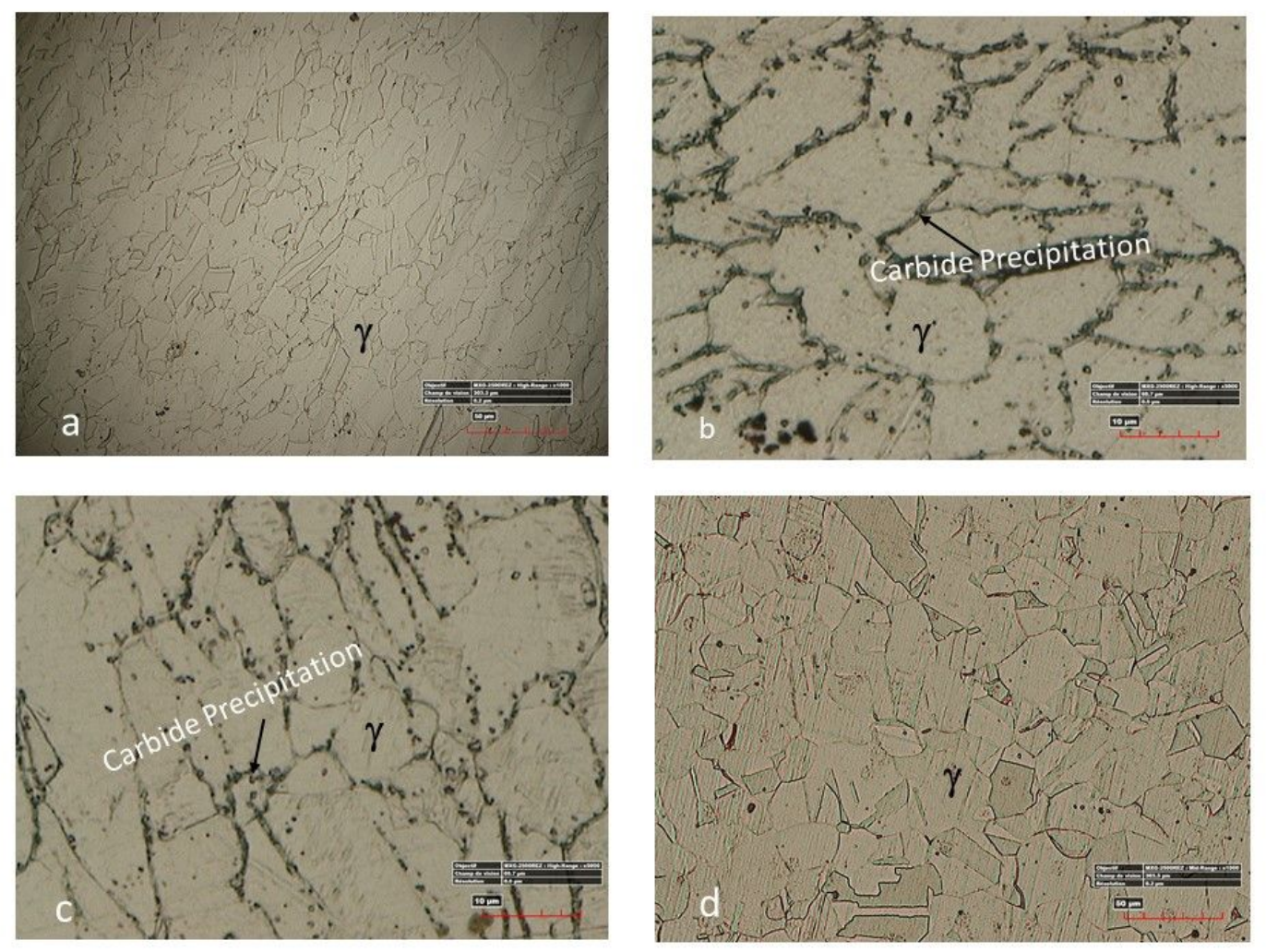

Fig. 5 Microstructure of Austenitic St. St. type 316L, a: as received, b: $750{ }^{\circ} \mathrm{C}$ for $1 \mathrm{hr}, \mathrm{c}: 850{ }^{\circ} \mathrm{C}$ for 1 hr, d: $1050^{\circ} \mathrm{C}$ for $10 \mathrm{~min}$.

\section{Discussion}

The results showed that the response of the alloys to the applied thermal treatments used in this study was different from one alloy to another. Table 2 showed that the austenitic stainless-steel type $316 \mathrm{~L}$ showed the least, or almost no response, to the heat treatments, then the DSS type 2304, while the highest and effective responses to retrieve the original phases were observed in alloys 2205 and 2507. Fig. 6 shows that the DSS alloy type 2304, which is a two phase-based alloy, showed a steady balance of the two austenite:ferrite ratio regardless of the applied heat treatments, as heating to high temperatures did not lead the alloy to change significantly. Table 2 and Fig. 6 show that the FC\% equals to 54.8 for the samples heated to $750{ }^{\circ} \mathrm{C}(1 \mathrm{hr}$ and $4 \mathrm{hrs})$ and $850{ }^{\circ} \mathrm{C}$ for all times, while the heating at 1050 for 4 hrs brought the $\mathrm{FC} \%$ similar to the ratio of the as-received sample, which was equal $62.2 \%$. Fig. 6 shows that both 2205 and 2507 alloys behave in a similar way, after heating at $750{ }^{\circ} \mathrm{C}$ the $\mathrm{FC} \%$ was started to decrease, though for 2507 took longer time than 2205 to start this reduction and this can be attributed to the chemical composition, higher $\mathrm{Cr} \%$, see Table 1 . Both alloys at $850{ }^{\circ} \mathrm{C}$ show lower $\mathrm{FC} \%$ than as received alloys, then the $\mathrm{FC} \%$ starts to increase again at $950{ }^{\circ} \mathrm{C}$ and by reaching $1050{ }^{\circ} \mathrm{C}$ the amount of $\mathrm{FC} \%$ was almost similar to that of the as received alloys. 
In terms of the hardness results, Fig. 1 showed that the heat treatments did not change the hardness values significantly, as the lowest hardness was observed on the samples which heat-treated at $850{ }^{\circ} \mathrm{C}$ and $1050{ }^{\circ} \mathrm{C}$.

More microstructural investigations were carried out to build a correlation between the $\mathrm{FC} \%$ and hardness values for the heat-treated 2304 alloys. Fig. 7a shows a type of intermetallic compound phase for a sample heat-treated at $850^{\circ} \mathrm{C}$ for $10 \mathrm{~min}$, which showed the lowest $\mathrm{FC}$ and hardness. Although the intermetallic compounds are known, generally, as brittle phases, consequently lead to the high hardness, researchers [5], [20] found that this is not always happening especially when the other factors, such as grain size and surface roughness, interacting together. On the other hand, Fig. $7 b$ shows the recrystallization phenomenon through reinitiating the ferrite phase on the austenite grain boundaries for the sample heated at $1050{ }^{\circ} \mathrm{C}$ for $4 \mathrm{hrs}$. Therefore, the low hardness values at this particular temperature can be attributed to the "recrystallization" or re-initiation residual stress free ferrite phase in the alloy. 

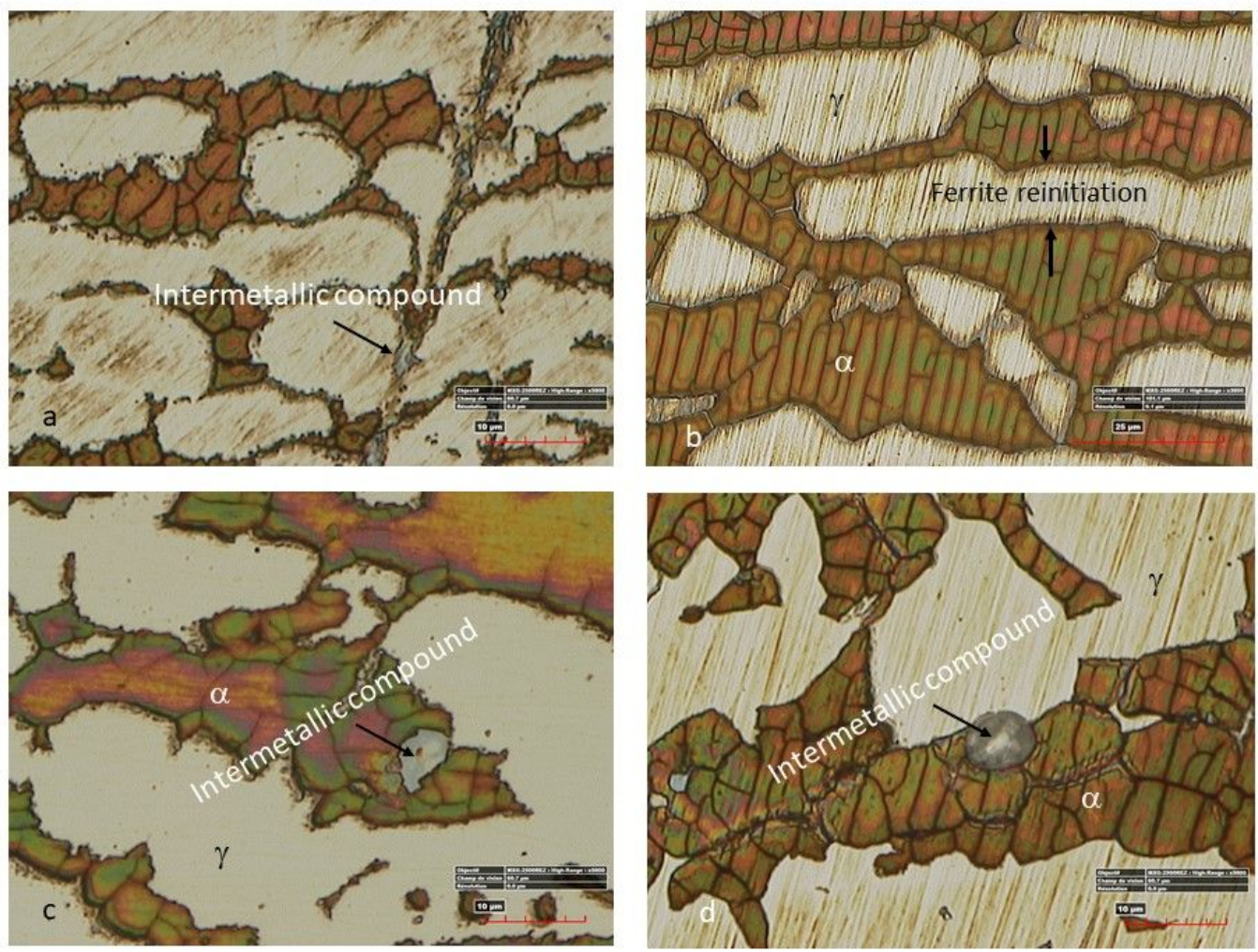

Fig. 7 Microstructure and intermetallic compounds, a: alloy 2304 heated at $850{ }^{\circ} \mathrm{C}$ for 10 minutes, b: alloy 2304 heated at $1050{ }^{\circ} \mathrm{C}$ for $4 \mathrm{hrs}$, c: alloy 2205 heated at $750^{\circ} \mathrm{C}$ for $10 \mathrm{~min}$. d: alloy 2507 heated at $850{ }^{\circ} \mathrm{C}$ for $10 \mathrm{~min}$.

The heat treatments which were applied in this study showed the most significant effects on both DSS alloy type 2205 and SDSS alloy type 2507 to retrieve their microstructures. In general, the results showed noticeable similarities between these two alloys, for example, the FC\% decreased with heating to temperatures, mainly at $850^{\circ} \mathrm{C}$ and $950{ }^{\circ} \mathrm{C}$, then at $1050^{\circ} \mathrm{C}$ the $\mathrm{FC} \%$ was noticeably increased, which almost reached the as received amounts, while - at these particular temperatures - the hardness values for both alloys, reached the minimum. Table 2 and Fig. 2, show that the highest hardness of 2205 and 2507 alloys was observed for the samples which heat-treated at $750{ }^{\circ} \mathrm{C}$ and $850{ }^{\circ} \mathrm{C}$ (for different times), which had the lowest ferrite contents. While, the lowest hardness was for the samples - which recovered their $\mathrm{FC} \%$ - heated to the highest temperature at $1050{ }^{\circ} \mathrm{C}$, almost all times. This correlation can be attributed to the reinitiation, due to recrystallization phenomenon, of new free residual stress ferrite grains.

On the other hand, in terms of increasing the hardness values with heating these two alloys, Fig. 7c and $\mathrm{d}$ show the microstructure of 2205 and 2507 heated for $10 \mathrm{~min}$ at $750{ }^{\circ} \mathrm{C}$ and $850{ }^{\circ} \mathrm{C}$ respectively. The figures show the initiation of intermetallic compounds which can be the reason behind increasing the hardness. The interpretation about the interrelation between the intermetallic phase, FC\% and hardness is not a straightforward approach, as researchers noticed such controversy results, and have been concluded that the intermetallic compounds and/or brittle phases, such as sigma phase, may present a wide range of hardness values due to the complexity of their structures. Moreover, the hardness results are dependent on the surface finish, which affects the scattering of the results concerning the average value [4], [26].

For the austenitic alloy, the results showed that the microstructure remained stable because the chemical composition of this group of alloys maintains austenitic phase at room temperature and at high temperatures, except the carbide precipitation phenomenon which occur at sensitization ranges, see Fig. 5. This stable austenite, due to the high $\mathrm{Ni}$ and $\mathrm{N}$ contents, see Table 1, do not allow heating to a high temperature to change the microstructure, for example to ferrite. In terms of the hardness values, Fig. $1 \mathrm{~d}$ showed that there are no large changes that happened in the hardness values between the heat-treated 
samples compared with the as-received alloy. The lowest hardness value at 750 and $850{ }^{\circ} \mathrm{C}$ can be attributed to the recovery and recrystallization phenomena, forming new grains with free residual stresses, due to passing the samples through these particular temperatures [10].

\section{Conclusions}

1- The alloys, 2205 and 2507, have completed recovered their ferrite:austenite ratio through heating to $1050{ }^{\circ} \mathrm{C}$, for all times.

2- The recovered samples showed low hardness values, which was attributed to the initiation of new ferrite phases, free residual stress grains, and/or due to the increase in the austenite phase and dilution of the intermetallics during the heat treatment.

3- Alloy type 2304 showed noticeable stability of $\mathrm{FC} \%$, as the ferrite:austenite ratio remained steady.

4- Austenitic stainless steel did not show changes, except chromium carbide precipitation by passing through sensitization ranges of temperatures at 750 and $850^{\circ} \mathrm{C}$.

\section{Acknowledgments}

The authors acknowledge the National Fund for Scientific Research (NFSR) for funding this grant to carry out this research at Mons University in Belgium. The grant covered travelling costs, two months staying in Belgium for the U.K. correspondent author and the materials used in this research.

\section{References}

[1] P. Boillot and J. Peultier, "Use of stainless steels in the industry: Recent and future developments," Procedia engineering, vol 83, pp. 309-321, 2014.

[2] A. Pramanik, G. Littlefair and A. K. Basak, "Weldability of duplex stainless steel," Materials and manufacturing processes, vol 30, no 9, pp. 1053-1068, Sep 2, 2015.

[3] A. N. Chaudhari, K. Dixit, G. S. Bhatia, B. Singh, P. Singhal and K. K. Saxena, "Welding behaviour of duplex stainless steel AISI 2205: AReview," Materials today: Proceedings, vol 18, pp. 2731-2737, 2019.

[4] A. A. Guimarães and P. R. Mei, "Precipitation of carbides and sigma phase in AISI type 446 stainless steel under working conditions," Journal of materials processing tech, vol 155-156, pp. 1681-1689, Nov 30, 2004.

[5] G. Argandoña, J. Palacio, C. Berlanga, M. Biezma, P. Rivero, J. Peña and R. Rodriguez, "Effect of the temperature in the mechanical properties of austenite, ferrite and sigma phases of duplex stainless steels using hardness, microhardness and nanoindentation techniques," Metals, vol 7, no 6, pp. 219, Jun 14, 2017.

[6] M. Gholami, M. Hoseinpoor and M. H. Moayed, "A statistical study on the effect of annealing temperature on pitting corrosion resistance of 2205 duplex stainless steel," Corrosion science, vol 94, pp. 156-164, May 2015.

[7] S. H. Arabi, M. Pouranvari and M. Movahedi, "Pathways to improve the austenite-ferrite phase balance during resistance spot welding of duplex stainless steels," Science and technology of welding and joining, vol 24, no 1, pp. 8-15, Jan 2, 2019.

[8] H. Tan, Z. Wang, Y. Jiang, L. Jiang, D. Han, J. Hong, L. Chen and J. Li, "Annealing temperature effect on the pitting corrosion resistance of plasma arc welded joints of duplex stainless steel UNS S32304 in 1.0 M NaCl," Corrosion science, vol 53, no 6, pp. 2191-2200, 2011. 
[9] H. Alinejad, B. Korojy, G.R. Ebrahimi Department of Materials, Polymer Engineering, Hakim Sabzevari University, 9. Sabzevar and Iran, "Microstructure and flow behavior of cast 2304 duplex stainless steel at elevated temperatures," vol 31, .

[10] A. Dehghan-Manshadi, M. R. Barnett and P. D. Hodgson, "Hot deformation and recrystallization of austenitic stainless steel: Part I. dynamic recrystallization," Metallurgical and materials transactions A, vol 39, no 6, pp. 1359-1370, Jun 2008.

[11] Fuad Khoshnaw, and Hussein Rahmatallah, "Stress corrosion cracking behaviour of welded duplex stainless steel," Advanced materials research, vol 89-91, pp. 709-714, 2010.

[12] F. Khoshnaw, V. Vitry and F. Delaunois, "Feasibility study of using thermal simulator to observe metallurgical aspects of welded duplex stainless steel," International journal of advances in science engineering and technology, vol 7, no 4, Jan 7, 2020.

[13] A. Kashiwar, N. P. Vennela, S. L. Kamath and R. K. Khatirkar, "Effect of solution annealing temperature on precipitation in 2205 duplex stainless steel," Materials characterization, vol 74, no Complete, pp. 55-63, Dec 2012.

[14] M. E. R. Cronemberger, S. Nakamatsu, C. A. Della Rovere, S. E. Kuri and N. A. Mariano, "Effect of cooling rate on the corrosion behavior of as-cast SAF 2205 duplex stainless steel after solution annealing treatment," Materials research, vol 18, no suppl 2, pp. 138-142, Oct 23, 2015.

[15] R. Badji, M. Bouabdallah, B. Bacroix, C. Kahloun, B. Belkessa and H. Maza, "Phase transformation and mechanical behavior in annealed 2205 duplex stainless steel welds," Materials characterization, vol 59, no 4, pp. 447-453, 2008.

[16] Z. Zhang, H. Jing, L. Xu, Y. Han, L. Zhao and J. Zhang, "Influence of microstructure and elemental partitioning on pitting corrosion resistance of duplex stainless steel welding joints," Applied surface science, vol 394, pp. 297-314, Feb 1, 2017.

[17] B. Deng, Z. Wang, Y. Jiang, T. Sun, J. Xu and J. Li, "Effect of thermal cycles on the corrosion and mechanical properties of UNS S31803 duplex stainless steel," Corrosion science, vol 51, no 12, pp. 2969-2975, 2009.

[18] V. D. Cojocaru, D. Raducanu, M. L. Angelescu, A. N. Vintila, N. Serban, I. Dan, E. M. Cojocaru and I. Cinca, "Influence of solution treatment duration on microstructural features of an industrial forged UNS S32750/1.4410/F53 super duplex stainless steel (SDSS) alloy," vol 69, .

[19] A. Ciuffini, S. Barella, C. Di Cecca, A. Gruttadauria, C. Mapelli and D. Mombelli, "Isothermal Austenite-Ferrite phase transformations and microstructural evolution during annealing in super duplex stainless steels," Metals, vol 7, no 9, pp. 368, Sep 14, 2017.

[20] N. Pettersson, S. Wessman, M. Thuvander, H. Peter, O. Joakim, P. Rachel and S. Hertzman, "Nanostructure evolution and mechanical property changes during aging of a super duplex stainless steel at $300^{\circ} \mathrm{C}, "$.

[21] E. Taban, "Toughness and microstructural analysis of superduplex stainless steel joined by plasma arc welding," Journal of materials science, vol 43, no 12, pp. 4309-4315, Jun 2008.

[22] I. Calliari, M. Pellizzari, M. Zanellato and E. Ramous, "The phase stability in $\mathrm{Cr}-\mathrm{Ni}$ and $\mathrm{Cr}-\mathrm{Mn}$ duplex stainless steels," Journal of materials science, vol 46, no 21, pp. 6916-6924, Nov 2011. 
[23] F. Khoshnaw and R. Gardi, "Sensitization assessment of duplex stainless steel using critical pitting temperature CPT method - ASTM G48," Buletinul journal of polytechnique institute in iasi, vol 3, .

[24] Abbas Eghlimi, Morteza Shamanian, and Keyvan Raeissi, "Dilution and ferrite number prediction in pulsed current

cladding of super-duplex stainless steel using RSM," vol 22, no 12, pp. 3657-3664, 2013.

[25] K. Vijayalakshmi, V. Muthupandi and R. Jayachitra, "Influence of heat treatment on the microstructure, ultrasonic attenuation and hardness of SAF 2205 duplex stainless steel," Materials science \& engineering $A$, vol 529, pp. 447-451, 2011.

[26] C. Walter and C. Mitterer, "3D versus 2D finite element simulation of the effect of surface roughness on nanoindentation of hard coatings," Surface \& coatings technology, vol 203, no 20, pp. 3286-3290, 2009. 